Open access e-Journal

Earth Science India, eISSN: $0974-8350$

Vol. 7 (I), January, 2014, pp. 1-14

http://www.earthscienceindia.info/

\title{
Long Term Variation in the Vertical Distribution of Tropospheric Ozone in India
}

\author{
Nandita D. Ganguly \\ Department of Physics, St. Xavier's College, Ahmedabad, India \\ Email: ganguly.nandita@gmail.com
}

\begin{abstract}
The seasonal, interannual and decadal variance in tropospheric ozone levels has been examined at three Indian cities: New Delhi, Pune and Thiruvananthapuram over the period from 1970 - 2009 using ozonesonde data. It is observed that the tropospheric ozone levels have not changed monotonically in a single direction over these years and the observed changes in ozone levels is a mixture of countervailing signals from both natural and anthropogenic factors. In general, the ozone concentration in the lower troposphere at all these stations is high during winter, decreases throughout summer reaching a minimum during monsoon and increases thereafter during post monsoon. For most part of the year, the ozone concentration in the lower troposphere is highest at Delhi followed by Pune and lowest at Thiruvananthapuram, while in the middle and upper troposphere it is highest at Delhi followed by Thiruvananthapuram and lowest at Pune. Linear trend of ozone partial pressure at different altitudes indicates that the maximum decreasing trend occurs around 10-13 km altitude. This altitude is observed to increase with increase in latitude.
\end{abstract}

Keywords: seasonal variation; interannual variation; decadal variation; tropospheric ozone

\section{Introduction}

Ozone is a minor constituent in earth's atmosphere, present mainly in two layers of the earth's atmosphere namely: stratosphere and troposphere. Tropospheric ozone constitutes around $10 \%$ of the atmospheric ozone. Total ozone in the troposphere at any location depends on the amount of its supply from the stratosphere, rate of photochemical production (Kirchhoff, 1988), transport from other regions and the rate of its destruction on the earth's surface either due to dry deposition or photochemical loss mechanisms (Junge, 1962; Crutzen, 1974; Van Dop et al., 1977). However, it is well established that the amount of tropospheric ozone generated by the photochemical reactions of chemical pollutants is much larger than the influx of ozone from the stratosphere (Crutzen, 1995; Crutzen et al., 1999), and the amount of ozone destroyed through photochemical loss mechanisms is several times greater than that destroyed as a result of surface deposition (Ripperton and Vukovich, 1971). Even though, the concentration of tropospheric ozone is low compared to that of stratospheric ozone, it plays a very significant role in controlling the chemical composition and climate of the troposphere, affecting life on earth. Increasing anthropogenic emissions of $\mathrm{NO}_{\mathrm{x}}$, hydrocarbons and $\mathrm{CO}$ in the recent years have caused appreciable increase of tropospheric ozone in many places worldwide (WMO, 1995), which may have important implications for regional air quality and climate. In view of these considerations, the seasonal, interannual and decadal variations in the tropospheric vertical ozone distribution have been examined at three Indian cities: New Delhi, Pune and Thiruvananthapuram using ozone sonde data. 


\section{Monitoring Sites}

The Indian subcontinent lies between $8^{\circ} \mathrm{N}-36^{\circ} \mathrm{N}$ latitude. The year may be divided broadly into four seasons. The winter season extends from December to February, followed by summer from March to May, monsoon from June to August and post monsoon from September to November. The prominent wind directions during summer are from the North West and west. During monsoon, winds blow from the southwest direction. During postmonsoon, winds blow from the southeast, east and northeast while during winter, northeast and north flow is predominant. New Delhi located in the extra tropics, Pune in the tropics and Thiruvananthapuram in southern India close to the sea in the tropics have entirely different geographical morphology and hence different local climatic conditions (Fig. 1).

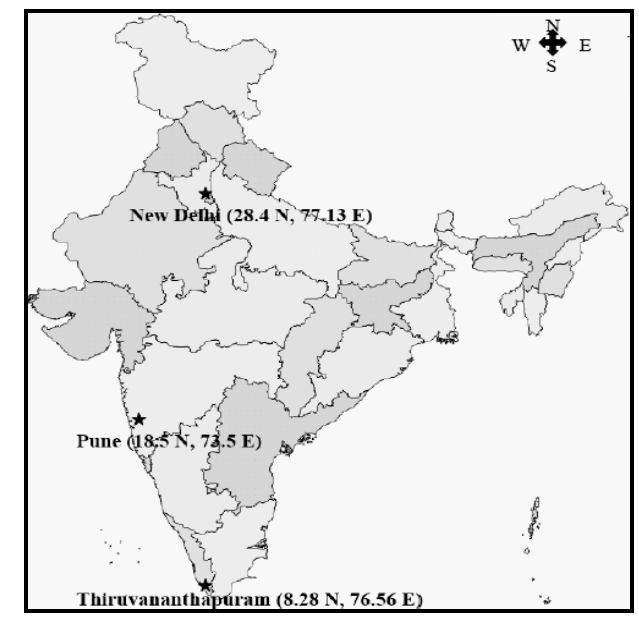

Fig.1: Map of India depicting the measurement sites.

New Delhi $\left(28.4^{\circ} \mathrm{N}, 77.13^{\circ} \mathrm{E} ; 214.42\right.$ meters above sea level), the capital of India is located in northern India and has an area of about 1,484 sq $\mathrm{km}$. It is a densely populated, cosmopolitan city. Sharp population growth accompanied by rapid industrialization has resulted in high levels of pollution in this city. Pune $\left(18.5^{\circ} \mathrm{N}, 73.5^{\circ} \mathrm{E} ; 560\right.$ meters above sea level) is a hilly city located on the leeward side of the Western Ghats, which forms a barrier from the Arabian Sea. It is one of the largest cosmopolitan cities in India, an important commercial centre having a temperate climate and is among the greenest urban areas in the country. Thiruvananthapuram $\left(8.28{ }^{\circ} \mathrm{N}, 76.56^{\circ} \mathrm{E} ; 60\right.$ meters above sea level), the capital city of the state Kerala, is situated by the sea shore on the west coast, near the southern tip of mainland India. It is bounded by Arabian Sea to its west and the Western Ghats to its east. The city spans over an area of around $250 \mathrm{sq} \mathrm{km}$ and is devoid of any large scale industrial activity.

\section{Data and Analysis}

Around 900 vertical ozone profiles at New Delhi, Pune and Thiruvananthapuram spanning over the period from 1970 - 2009 (profiles were not available during the years 1977 -1981, 1987-1993, 2001, 2004 and 2005) were obtained from the World Ozone and Ultraviolet Radiation Data Centre (WOUDC). These profiles were measured by India Meteorological Department (IMD) using balloon-borne electrochemical ozone sondes, flown monthly/bimonthly, from approximately $1000 \mathrm{hPa}$ to $1 \mathrm{hPa}$ with an accuracy of $0.5 \mathrm{hPa}$. The pressure levels were equated to their equivalent altitude in $\mathrm{km}$. Cold point tropopause was 
Open access e-Journal

Earth Science India, eISSN: $0974-8350$

Vol. 7 (I), January, 2014, pp. 1-14

http://www.earthscienceindia.info/

identified from the temperature data obtained from the ozone sonde profiles. All the vertical ozone profiles for each station were first grouped into four decades spanning over the years 1970-1976, 1982-1986, 1994-1999 and 2000-2009. The profiles within each decade were averaged and the variation of vertical ozone distribution in the troposphere was compared for these four decades. Thereafter, all the profiles were averaged annually to study the interannual variations within each decade. Further, all the profiles over the period from 20002009 were grouped into four seasons: summer (MAM), monsoon (JJA), post monsoon (SON) and winter (DJF). These profiles were averaged to study the seasonal changes in vertical ozone distribution at New Delhi, Pune and Thiruvananthapuram at different tropospheric altitudes.

\section{Discussion}

\section{Decadal variation of vertical ozone distribution in the troposphere:}

Decadal variation of vertical ozone distribution in the troposphere at New Delhi, Pune and Thiruvananthapuram over the period from 1971-2009 is plotted in Fig.2. The decadal variation at New Delhi indicates, that ozone concentration at all altitudes in the troposphere has increased consistently from 1971-1999, but decreased during 2000-2009. Rapid increase in pollution levels were reported during the period 1989-1996, with peak pollution reported in the year 1996 (http://dpcc.delhigovt.nic.in/pdf/cleanerair.pdf). The increasing trend in Ozone levels may be attributed to the influence of local factors, such as a sharp population growth accompanied by uncontrolled urbanization and rapid industrialization, resulting in high levels of pollution from 1971-1999. The decrease in ozone levels in the recent decade may be attributed to the advanced emission norms of vehicles; cap introduced in the number of auto rickshaws; conversion of buses to compressed natural gas (CNG), mandatory use of CNG as fuel for new light commercial vehicles; and restriction of commercial vehicles from entering the city, which reduced the contribution of vehicular sector towards air pollution in the subsequent years. This is supported by the fact that there is a significant and consistent improvement in the air quality from the year 1996 to the year 2002 (http://dpcc.delhigovt.nic.in/pdf/cleanerair.pdf).

The decadal variation at Pune indicates that ozone concentration at all altitudes in the troposphere was very high during 1982-1986 compared to 1970-1976. In the upper troposphere it decreased during 1994-1999 reaching a minimum during 2000-2009, while in the middle and lower troposphere it increased during 1994-1999 reaching a maximum during 2000-2009.

The ozone concentration at Thiruvananthapuram has increased consistently from 1973-2009 in the lower troposphere, while in the upper troposphere, it has decreased consistently from 1973-1999 and increased slightly during the period 2000-2009 compared to 1994-1999. Similar to Delhi, the increase in middle and lower tropospheric ozone levels at Pune and Thiruvananthapuram may also be attributed to the influence of sharp population growth accompanied by uncontrolled urbanization and rapid industrialization, resulting in higher levels of pollution in the recent decades. 

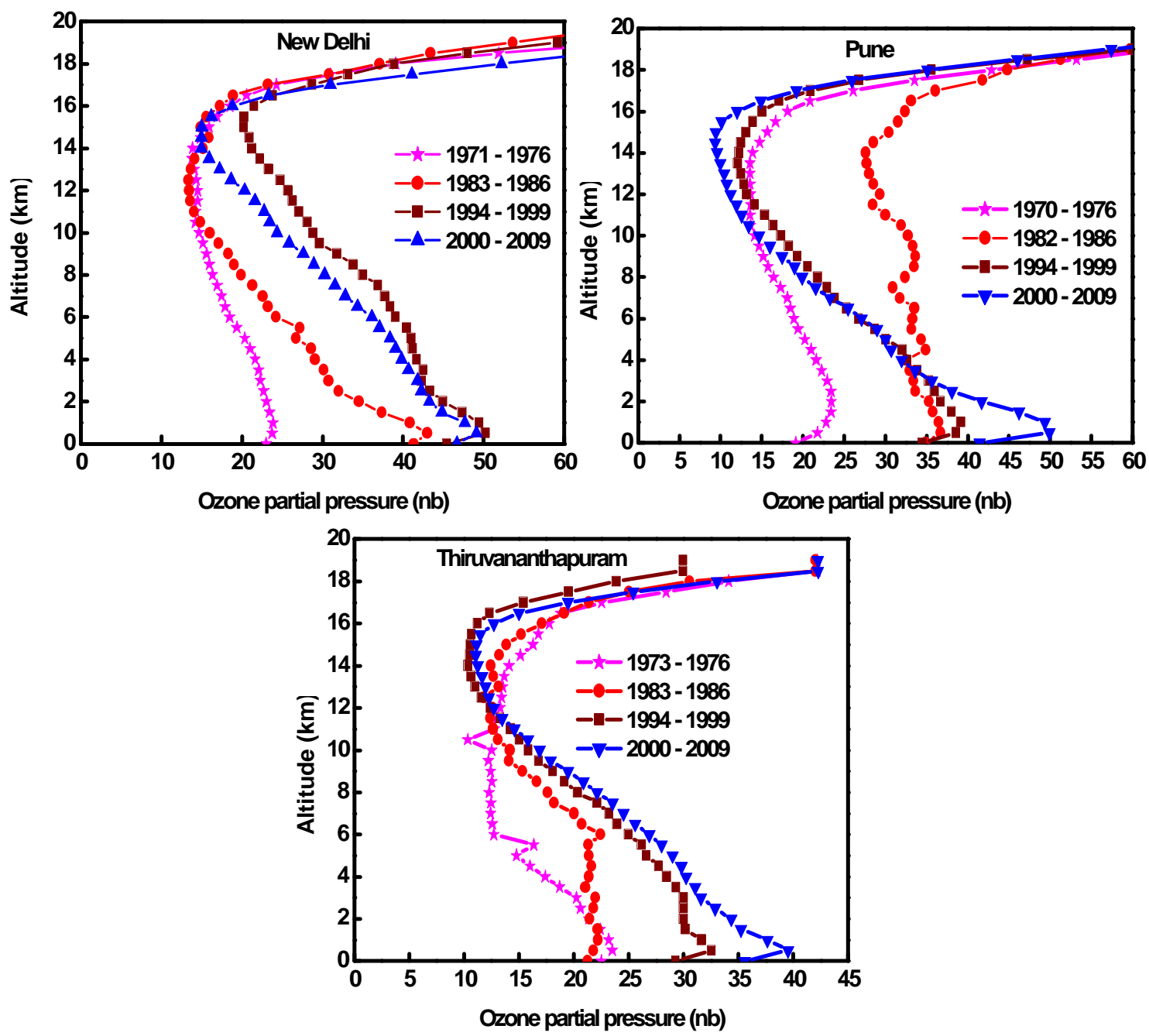

Fig. 2: Decadal variation of vertical ozone distribution in the troposphere at New Delhi, Pune and Thiruvananthapuram over the period from 1971 - 2009. (Source of data: IMD and World Ozone and Ultraviolet Radiation Data Centre)

Apart from changes in ozone levels due to the above mentioned causes, a number of natural factors such as the high natural variability in ozone abundances due to the solar cycle, transport of air from one region to another (Weatherhead and Andersen, 2006), El Niño Southern Oscillation (Shiotani, 1992; Ganguly and Iyer, 2006), Quasi-Biennial Oscillation (Holllandsworth et al., 1995), Solar storms (Ganguly, 2010), Lightning (Wang and Isaksen 1995), aircraft emissions (Tremmel et al., 1998), nuclear testing (Christie, 1976) and emissions from coal fires (Ganguly, 2008), may also have a significant influence on the tropospheric ozone levels. The change in ozone concentration under the influence of these natural and anthropogenic factors varies from one event to another, as it depends on the magnitude of the event and geographical location of the site. This suggests that the observed decadal changes in vertical ozone distribution are a mixture of countervailing signals from both natural and anthropogenic factors. 
Open access e-Journal

Earth Science India, eISSN: $0974-8350$

Vol. 7 (I), January, 2014, pp. 1-14

http://www.earthscienceindia.info/

\section{Seasonal changes in tropospheric ozone profile:}

The ozone concentration in the lower troposphere at all these stations is high during winter, decreases throughout summer reaching a minimum value during monsoon and increases thereafter during post monsoon (Fig. 3). This may be because during winter as the air begins to cool, ozone rich air grows denser and sinks to lower altitudes, resulting in an increase in lower tropospheric ozone. Ozone is produced due to photo oxidation of pollutants (carbon monoxide and hydrocarbons) in presence of adequate amount of nitrogen oxides at lower altitudes. The general wind pattern from the north and north east direction during winter in India, takes the polluted continental air down to the experimental sites, resulting in high ozone levels. Apart from this, decrease in temperature increases the life time of ozone during winter (Debaje and Kakade, 2009). During summer, the large solar flux acts upon $\mathrm{NO}_{\mathrm{x}}$ ( $\mathrm{NO}$ and $\mathrm{NO}_{2}$ ) and hydrocarbons transported from the interior landmass resulting in local photochemical production. During monsoon, a decrease in ozone concentration occurs due to wash out of ozone and its precursors by pure monsoonal air masses. Moreover, reduced solar radiation due to the presence of clouds also reduces the rate of photochemical production. The winds blowing from the east during post monsoon transports the polluted inland air to the experimental sites, resulting in high ozone levels.

The amount of ozone in the lower troposphere depends on both transport and chemistry depending on the region and season of the year, while upper and middle tropospheric ozone concentration is dominated by dynamical influences such as wave driving of the stratospheric circulation and tropopause folds (Ganguly and Iyer, 2005). A comparison of tropospheric ozone levels at these three cities (Fig. 4) is summarized in Table-1. It is observed that for most part of the year, the ozone concentration in the lower troposphere is highest at Delhi followed by Pune and lowest at Thiruvananthapuram, which may be on account of photo chemical production and transport from other regions. In the middle and upper troposphere, it is highest at Delhi followed by Thiruvananthapuram and lowest at Pune. This may be because in the tropics (Thiruvananthapuram), lifting of polluted ozone-rich surface air leads to reduced lower tropospheric and enhanced middle and upper tropospheric ozone, and conversely, in the extra tropics (Delhi), sinking motion from the stratosphere in to the troposphere results in higher middle and upper tropospheric ozone concentration (Ganguly and Tzanis, 2011).

Ganguly and Iyer (2009) have observed that the stratospheric column ozone for different Indian latitude belts shows a small decreasing trend, which increases with increase in latitude. Modeling studies suggest that an increase in UV-B due to stratospheric ozone depletion causes decrease in tropospheric ozone in a clean environment (very low $\mathrm{NO}_{\mathrm{x}}$ ), and an increase in tropospheric ozone in polluted areas (Thompson et al., 1989; Madronich and Granier, 1992). It may be possible, that as the stratospheric ozone depletion and $\mathrm{NO}_{\mathrm{x}}$ pollution is higher at Delhi followed by Pune and Thiruvananthapuram the ozone concentration in the lower troposphere is higher at Delhi followed by Pune and Thiruvananthapuram. The discrepancies observed during post monsoon and winter seasons may be because, apart from changes in UV-B due to stratospheric ozone depletion, a large number of other natural and anthropogenic factors also influence the tropospheric ozone chemistry. More over due to lack of in situ observations of chemical species $\left(\mathrm{CO}, \mathrm{CH}_{4}, \mathrm{H}_{2} \mathrm{O}\right.$, 
and $\left.\mathrm{NO}_{\mathrm{x}}\right)$ at these altitudinal levels, it is difficult to conclude strongly on the chemical and physical processes leading to this observed trend.

\section{Inter annual variation of vertical ozone distribution in the troposphere:}

Interannual changes are more prominent at lower altitudes. However the interannual variations within each decade indicate that the ozone levels have not changed monotonically in a single direction over these years at any of these stations. This suggests that the observed inter annual change is a mixture of countervailing signals from both natural and anthropogenic factors (Fig. 5 - 7).
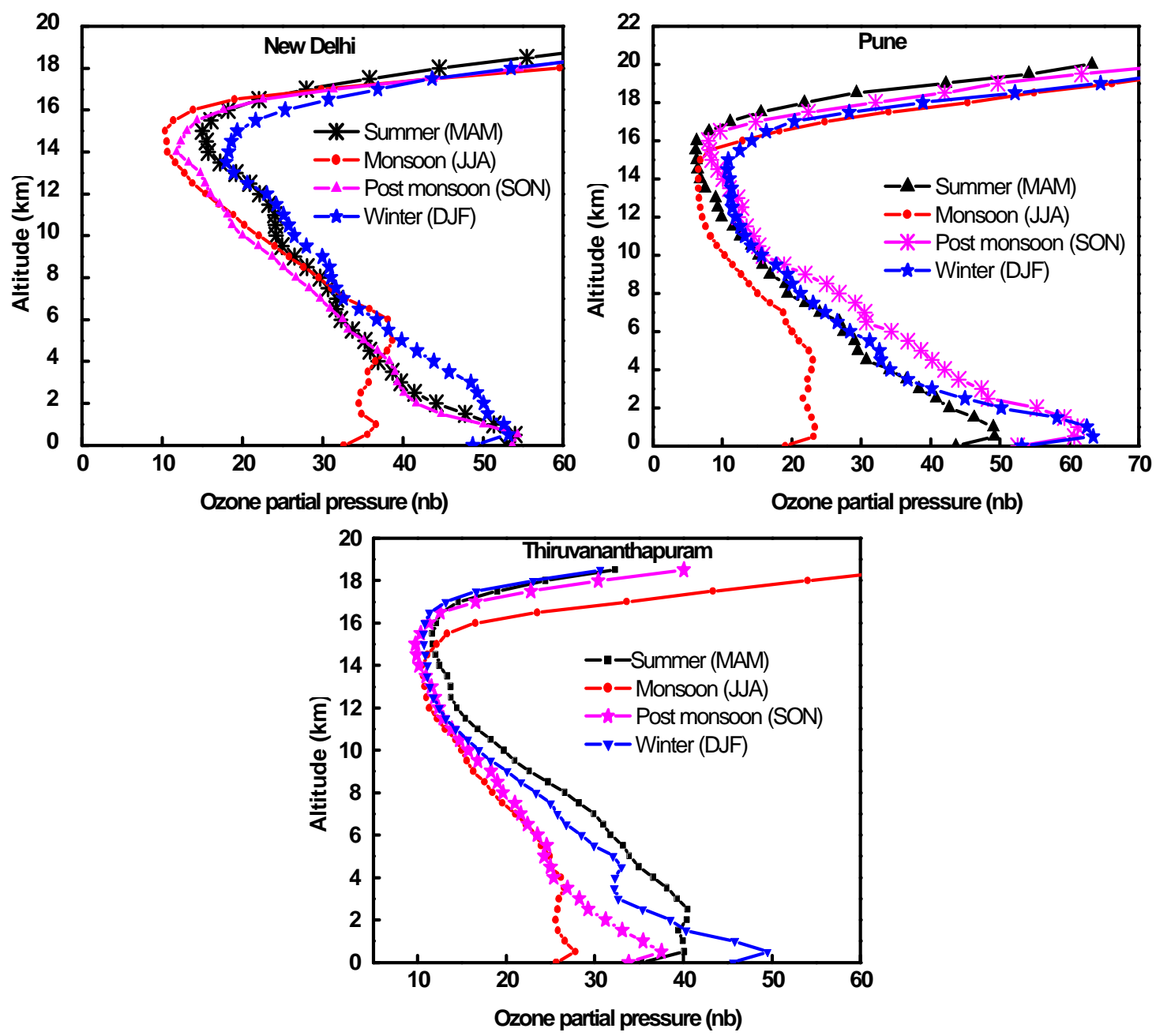

Fig. 3: Seasonal variation of vertical ozone distribution in the troposphere at New Delhi, Pune and Thiruvananthapuram over the period from 2000-2009 (Source of data: IMD and World $\mathrm{O}_{3}$ and Ultraviolet Radiation Data Centre). 
Open access e-Journal

Earth Science India, eISSN: $0974-8350$

Vol. 7 (I), January, 2014, pp. 1-14

http://www.earthscienceindia.info/
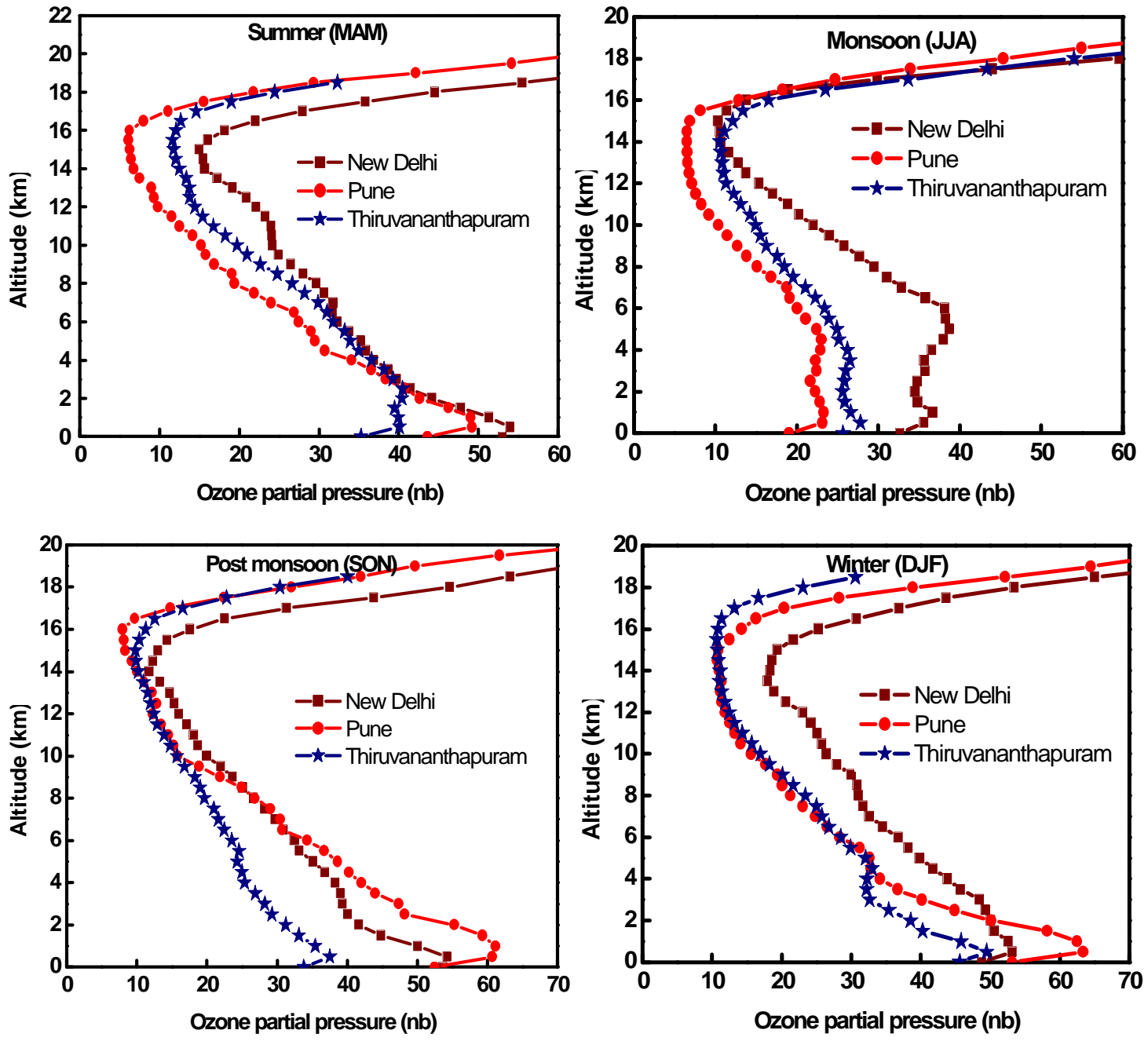

Fig. 4: Comparison of vertical ozone distribution in the troposphere for different seasons at New Delhi, Pune and Thiruvananthapuram over the period from 2000-2009 (Source of data: IMD and World $\mathrm{O}_{3}$ and Ultraviolet Radiation Data Centre).

\section{Long-term trend of tropospheric ozone:}

Linear trend of ozone partial pressure at different altitudes was examined over the period from 1994 - 2009. The results are summarized in Table-2. Ozone partial pressure at New Delhi indicates a decreasing trend at all altitudes up to $15 \mathrm{~km}$, above which it exhibits an increasing trend. The maximum decreasing trend is observed at $13 \mathrm{~km}$ altitude. At Pune, ozone partial pressure indicates an increasing trend up to $2 \mathrm{~km}$, above which it exhibits a decreasing trend at all altitudes. The maximum decreasing trend is observed at $11 \mathrm{~km}$ altitude. Ozone partial pressure at Thiruvananthapuram indicates an increasing trend at all altitudes except at $9 \mathrm{~km}$ altitude. However, no consistent decreasing trend with increase in altitude was observed at any of these stations The typical trend in ozone partial pressure observed at these three cities may be because, reduction in stratospheric ozone results in 
higher penetration of UV-B radiation to the troposphere, which in turn increases the photo dissociation rates of tropospheric ozone and other trace gases (Solomon et al., 2003). De Winter-Sorkina (2001 a; $2001 \mathrm{~b}$ ) observed that the trend in ozone photo dissociation rate coefficients due to stratospheric ozone depletion increased with altitude, reaching a maximum at about $8-12 \mathrm{~km}$, the exact altitude depending on latitude. In the present study, the maximum decreasing trend in ozone partial pressure occurs around $10-13 \mathrm{~km}$ altitude and the altitude of this maximum decreasing trend is observed to increase with increase in latitude.

Table- 1: Tropospheric ozone levels observed at Delhi, Pune and Thiruvananthapuram for different seasons of the years $2000-2009$. The names of the cities are written in the order of descending ozone levels. (Source of data: IMD and World Ozone and Ultraviolet Radiation Data Centre)

\begin{tabular}{|c|c|c|c|}
\hline & $\begin{array}{c}\text { Lower Troposphere } \\
\text { (order of max to min } \\
\text { ozone) }\end{array}$ & $\begin{array}{c}\text { Middle troposphere } \\
\text { (order of max to min } \\
\text { ozone) }\end{array}$ & $\begin{array}{l}\text { Upper troposphere } \\
\text { (order of max to min } \\
\text { ozone) }\end{array}$ \\
\hline Summer & $\begin{array}{c}\text { Delhi } \\
\text { Pune } \\
\text { Thiruvananthapuram }\end{array}$ & $\begin{array}{c}\text { Delhi } \\
\text { Thiruvananthapuram } \\
\text { Pune }\end{array}$ & $\begin{array}{c}\text { Delhi } \\
\text { Thiruvananthapuram } \\
\text { Pune }\end{array}$ \\
\hline Monsoon & $\begin{array}{c}\text { Delhi } \\
\text { Thiruvananthapuram } \\
\text { Pune }\end{array}$ & $\begin{array}{c}\text { Delhi } \\
\text { Thiruvananthapuram } \\
\text { Pune }\end{array}$ & $\begin{array}{c}\text { Delhi } \\
\text { Thiruvananthapuram } \\
\text { Pune }\end{array}$ \\
\hline $\begin{array}{c}\text { Post- } \\
\text { monsoon }\end{array}$ & $\begin{array}{c}\text { Pune } \\
\text { Delhi } \\
\text { Thiruvananthapuram }\end{array}$ & $\begin{array}{c}\text { Pune } \\
\text { Delhi } \\
\text { Thiruvananthapuram }\end{array}$ & $\begin{array}{c}\text { Delhi } \\
\text { Pune / } \\
\text { Thiruvananthapuram }\end{array}$ \\
\hline Winter & $\begin{array}{c}\text { Pune/ Delhi } \\
\text { Delhi / Pune } \\
\text { Thiruvananthapuram }\end{array}$ & $\begin{array}{c}\text { Delhi } \\
\text { Pune / } \\
\text { Thiruvananthapuram }\end{array}$ & $\begin{array}{c}\text { Delhi } \\
\text { Pune / } \\
\text { Thiruvananthapuram }\end{array}$ \\
\hline
\end{tabular}

Linear trend of monthly maximum surface ozone studied by Ganguly (2012) over the period from 1998 - 2008 indicates, that the surface ozone levels are observed to be highest at Delhi followed by Pune and lowest at Thiruvananthapuram. The ozone levels at Pune and Thiruvananthapuram indicate a small decreasing trend $\left(-0.33 \mathrm{ppbv} \mathrm{yr}^{-1}\right.$ and $-0.191 \mathrm{ppbv} \mathrm{yr}^{-1}$ respectively), while that at New Delhi indicates a small increasing trend $\left(0.25 \mathrm{ppbv} \mathrm{yr}^{-1}\right)$ over this period of study. This may be because an increasing trend in UV-B due to stratospheric ozone depletion might have caused a decrease in surface ozone in a clean environment (Pune and Thiruvananthapuram), and an increase in tropospheric ozone in a polluted environment (New Delhi) as suggested by Thompson et al., (1989) and Madronich and Granier (1992). 
Open access e-Journal

Earth Science India, eISSN: $0974-8350$

Vol. 7 (I), January, 2014, pp. 1-14

http://www.earthscienceindia.info/
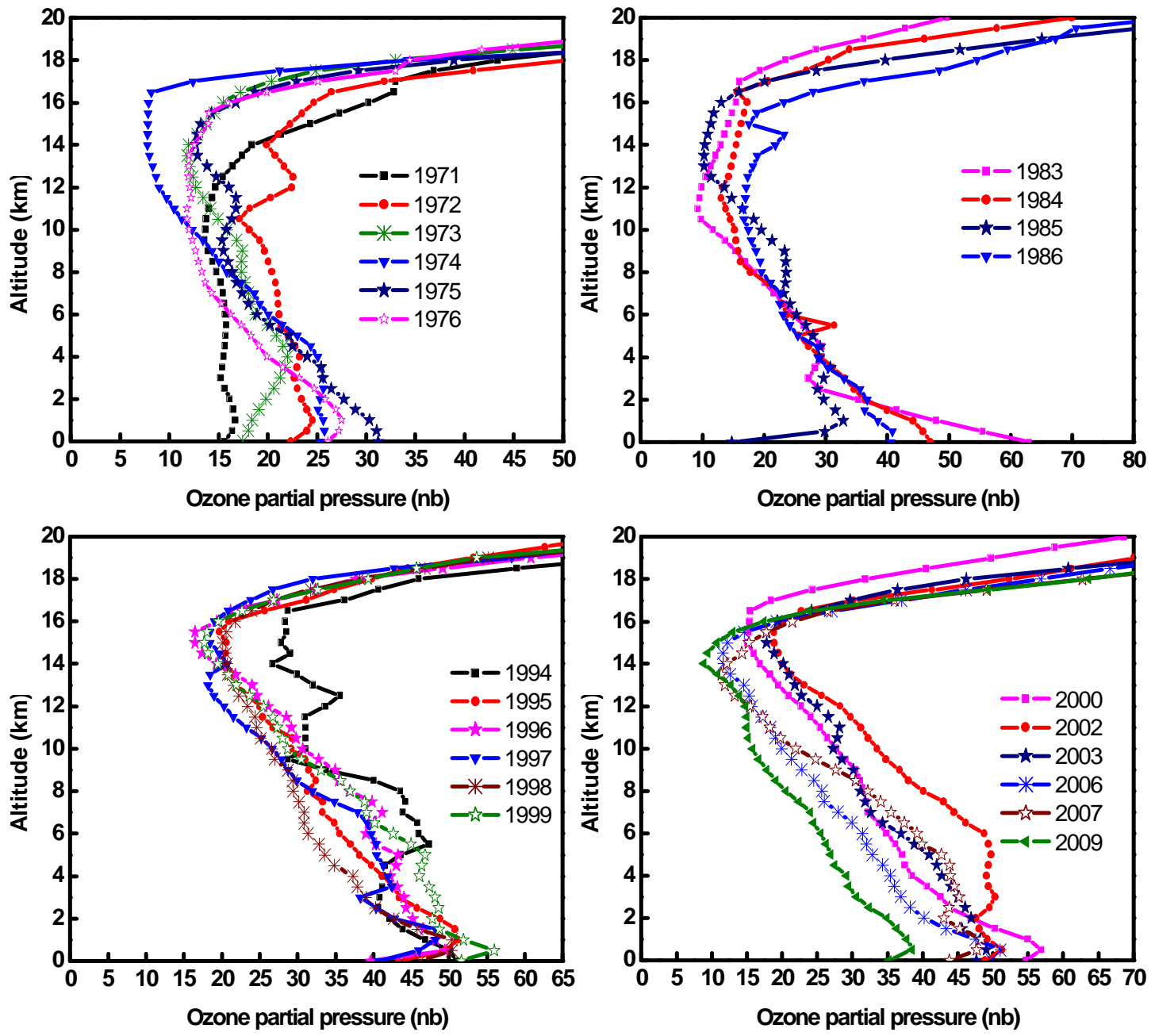

Fig. 5: Inter annual variation of vertical ozone distribution in the troposphere at New Delhi for four decades over the period from 1971-2009. The profiles have been averaged yearly (Source of data: IMD and World Ozone and Ultraviolet Radiation Data Centre). 

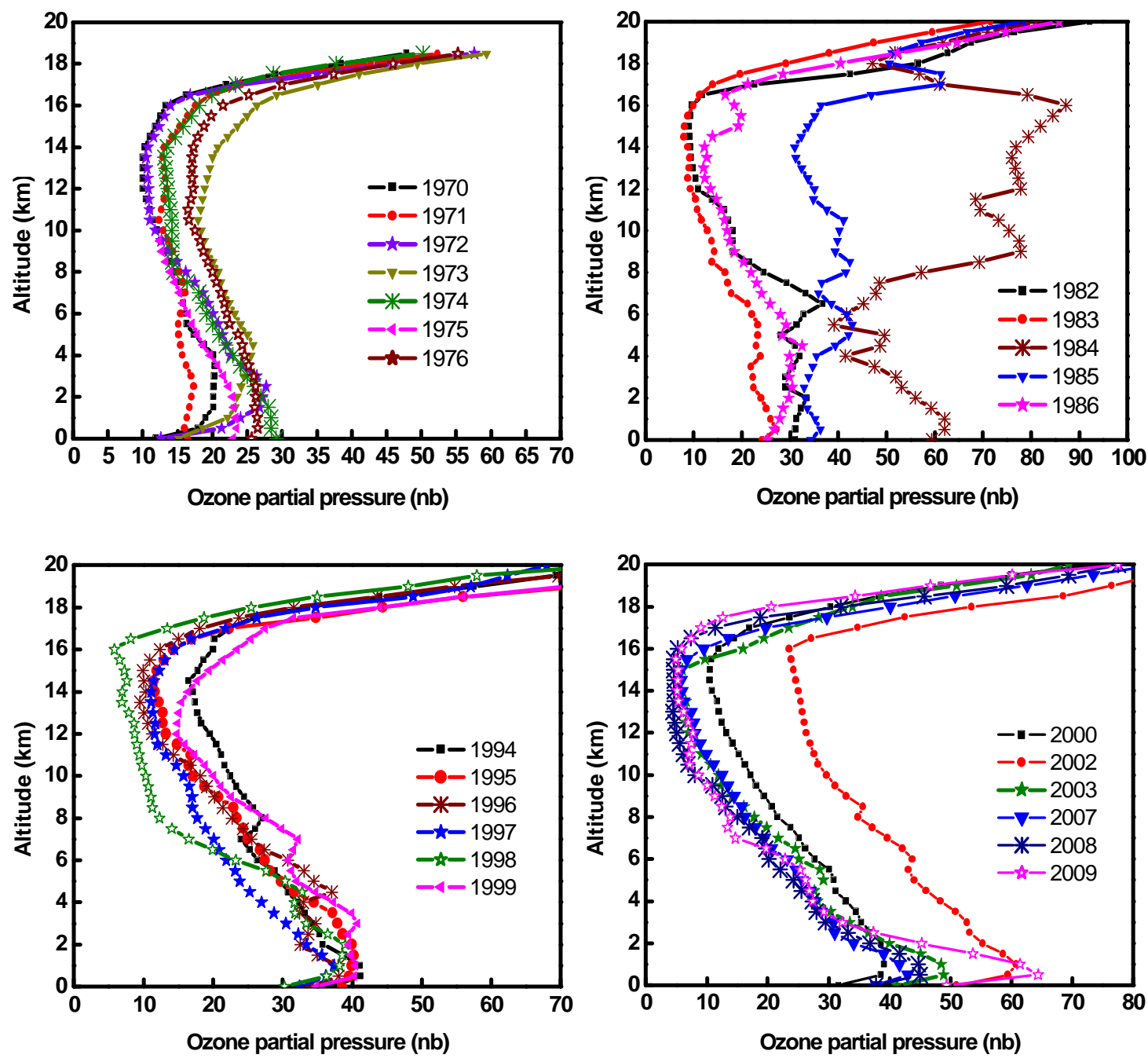

Fig. 6: Inter annual variation of vertical ozone distribution in the troposphere at Pune for four decades over the period from $1970-2009$. The profiles have been averaged yearly (Source of data: IMD and World Ozone and Ultraviolet Radiation Data Centre). 
Open access e-Journal

Earth Science India, eISSN: $0974-8350$

Vol. 7 (I), January, 2014, pp. 1-14

http://www.earthscienceindia.info/
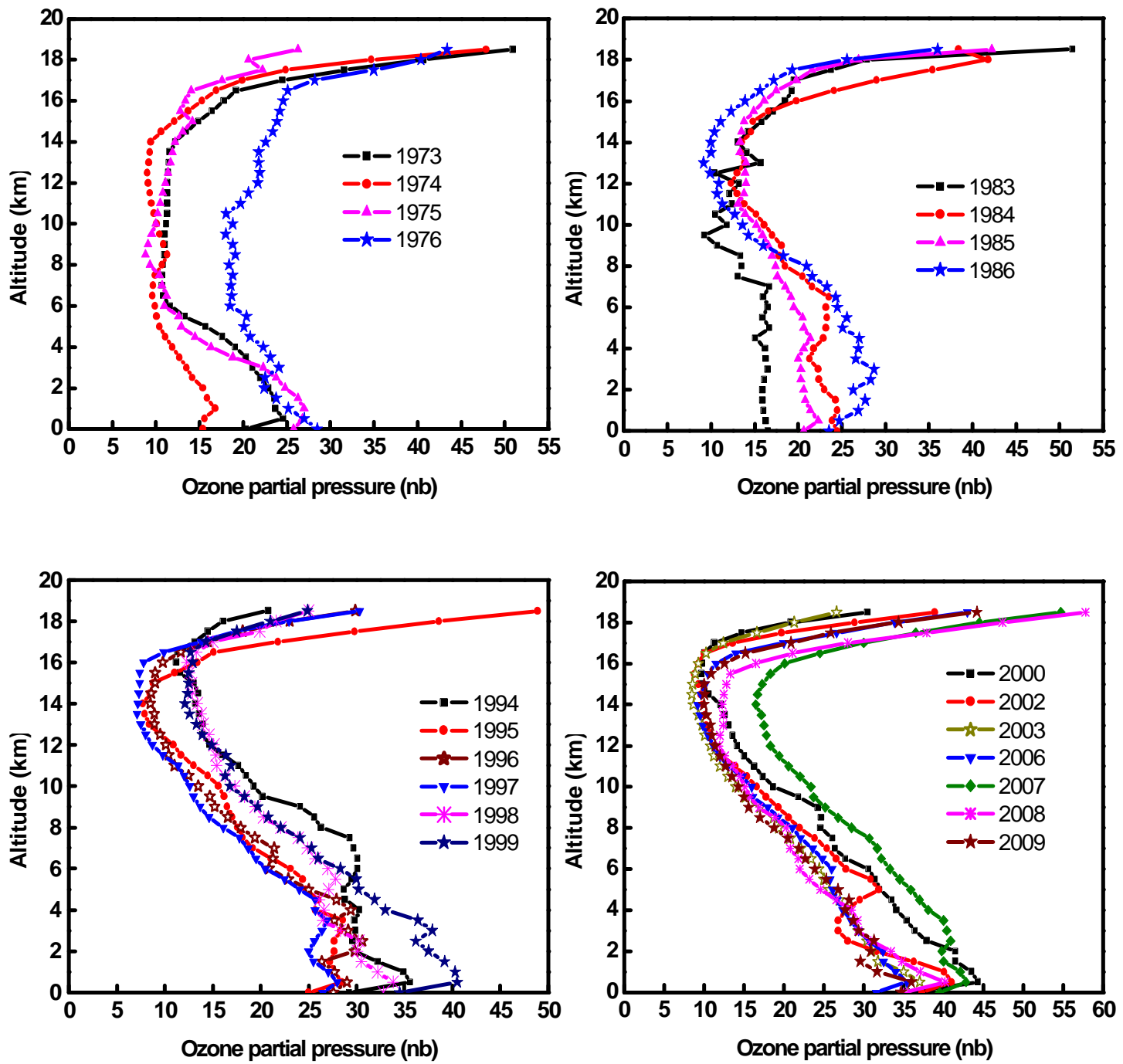

Fig. 7: Inter annual variation of vertical ozone distribution in the troposphere at Thiruvananthapuram for four decades over the period from 1973-2009. The profiles have been averaged yearly (Source of data: IMD and World Ozone and Ultraviolet Radiation Data Centre). 
Table- 2: Linear trend of Ozone partial pressure at different altitudes at New Delhi, Pune and Thiruvananthapuram over the period from 1994 - 2009. (Source of data: WOUDC)

\begin{tabular}{|c|c|c|c|}
\hline $\begin{array}{c}\text { Altitude } \\
(\mathrm{km})\end{array}$ & $\begin{array}{c}\text { Trend of Ozone partial } \\
\text { pressure }\left(\mathrm{nb} \mathrm{yr}^{-1}\right) \text { at } \\
\text { New Delhi }\end{array}$ & $\begin{array}{c}\text { Trend of Ozone } \\
\text { partial pressure }(\mathrm{nb} \\
\left.\mathrm{yr}^{-1}\right) \text { at Pune }\end{array}$ & $\begin{array}{c}\text { Trend of Ozone partial } \\
\text { pressure }\left(\mathrm{nb} \mathrm{yr}^{-1}\right) \mathrm{at} \\
\text { Thiruvananthapuram }\end{array}$ \\
\hline 01.0 & -0.4193 & 0.9855 & 0.4177 \\
\hline 02.0 & -0.4177 & 0.3275 & 0.3526 \\
\hline 03.0 & -0.3097 & -0.236 & 0.1786 \\
\hline 04.0 & -0.3935 & -0.3313 & 0.1414 \\
\hline 05.0 & -0.5203 & -0.2931 & 0.1376 \\
\hline 06.0 & -0.594 & -0.2877 & 0.0678 \\
\hline 07.0 & -0.7545 & -0.4074 & 0.0567 \\
\hline 08.0 & -0.8044 & -0.5509 & 0.042 \\
\hline 09.0 & -0.7493 & -0.5561 & 0.0561 \\
\hline 10.0 & -0.7966 & -0.6312 & $\mathbf{0 . 0 0 5 1}$ \\
\hline 11.0 & -0.798 & $\mathbf{- 0 . 6 5 1 4}$ & 0.0316 \\
\hline 12.0 & -0.8823 & -0.5243 & 0.055 \\
\hline 13.0 & $\mathbf{- 0 . 9 1 1 4}$ & -0.517 & 0.1311 \\
\hline 14.0 & -0.8838 & -0.5496 & 0.1291 \\
\hline 15.0 & -0.7023 & -0.6005 & 0.1533 \\
\hline 16.0 & 1.8171 & -0.5871 & 0.3097 \\
\hline 17.0 & 0.4502 & -0.5071 & 0.7178 \\
\hline
\end{tabular}

\section{Conclusion}

The seasonal, interannual and decadal variance in ozone levels at different tropospheric altitudes has been examined at three Indian cities: New Delhi, Pune and Thiruvananthapuram for the period from 1970-2009 using ozonesonde data. The Decadal and interannual variations within each decade indicate that the tropospheric ozone levels have not changed monotonically in a single direction over these years at any of these stations and the observed changes in ozone levels is a mixture of countervailing signals from both natural and anthropogenic factors. The ozone concentration in the lower troposphere at all these stations is high during winter, decreases throughout summer reaching a minimum during monsoon and increases thereafter during post monsoon. For most part of the year, the ozone concentration in the lower troposphere is highest at Delhi followed by Pune and lowest at Thiruvananthapuram, while in the middle and upper troposphere it is highest at Delhi followed by Thiruvananthapuram and lowest at Pune. Linear trend of ozone partial pressure over the period from 1994 - 2009 indicates that maximum decreasing trend in ozone partial 
Open access e-Journal

Earth Science India, eISSN: $0974-8350$

Vol. 7 (I), January, 2014, pp. 1-14

http://www.earthscienceindia.info/

pressure occurs around $10-13 \mathrm{~km}$ altitude and this altitude is observed to increase with increase in latitude.

Acknowledgments: The ozone profiles were measured at India Meteorological Department and were retrieved from the World Ozone and Ultraviolet Radiation Data Centre. Topographic map of India depicting the measurement sites was obtained from the website: www.mapsindia.com. The author acknowledges her gratitude to IASc - INSA - NASI for providing grant under Summer Research Fellowship Programme, Dr. Prabha Nair, Space Physics Laboratory, VSSC Thiruvananthapuram and Dr. A. K. Singh, Department of Physics, Lucknow University for their for valuable suggestions and Prof. J. N. Goswami, Director of Physical Research Laboratory Ahmedabad for providing library facility.

\section{References}

Christie, A. D. (1976) Atmospheric ozone depletion by nuclear weapons testing. J. Geophys. Res., v. 81, pp. 2583-2594.

Crutzen, P.J., Lawrence, M.G. and Poschl, U. (1999) On the background photochemistry of tropospheric ozone. Tellus, Serial A, v. 51, pp. 123-146.

Crutzen, P.J. (1995) Ozone in the troposphere, in Composition, Chemistry and Climate of the Atmosphere. In: H. B. Singh (ed.), pp. 349-393, Van Nostrand Reinhold, New York.

Crutzen, P.J., Lawrence, M.G. and Poschl, U. (1999) On the background photochemistry of tropospheric ozone. Tellus, Serial A, v. 51, pp. 123-146.

De Winter-Sorkina, R. (2001a) Impact of ozone layer depletion I: Ozone depletion climatology, Atmos. Environ., v. 35, pp. 1609-1614.

De Winter-Sorkina, R. (2001b) Impact of ozone layer depletion II: Changes in Photo dissociation rates and tropospheric composition, Atmos.Environ., v. 35, pp. 1615- 1625 .

Debaje, S. B. and Kakade, A. D. (2009) Surface ozone variability over western Maharashtra, India. J. Hazard. Mater., v. 16, pp. $686-700$.

Ganguly, N. D. and Iyer, K. N. (2006) Effect of El Niño Southern Oscillation on the ozone concentration of Indian cities. Ind. J. of Phys., v. 80 (3), pp. $229-234$.

Ganguly, N. D. and Iyer, K. N. (2009) Long-term variations of surface air temperature during summer in India. Int. J. Climatol., v. 29 (5), pp. 735-746.

Ganguly, N. D. and Iyer, K. N. (2005) Study of variations in columnar ozone concentration at Rajkot. J. Ind. Geophys. Union, v. 9 (3), pp. $189-196$.

Ganguly, N. D. (2010) Influence of solar proton events during the declining phase of solar cycle 23 on the total ozone concentration in India. Int. J. of Remote Sensing, v. 31(2), pp. 313-322.

Ganguly, N. D. (2012) Influence of Stratospheric Intrusion on the Surface Ozone Levels in India, ISRN Meteorology, Article ID 625318, doi:10.5402/2012/625318

Ganguly, N. D. (2008) Low level of stratospheric ozone near the Jharia coal field in India. Journal of Earth System Sciences, v. 117, pp. $79-82$.

Ganguly, N. D. and Tzanis, C. (2011) Study of Stratosphere-Troposphere exchange events of ozone in India and Greece using ozonesonde ascents. Meteorological applications, v.18, pp. 467-474.

Holllandsworth, S.M., Bowman, K.P., and Mc Peters, R.D. (1995) Observational study of the quasi-biennial oscillation in ozone. J. Geophys. Res., v. 100, pp. 7347-7361.

Junge, C.E. (1962) Global ozone budget and exchange between stratosphere and troposphere. Tellus, v. 14, pp. 363

Kirchhoff, V.W. (1988) Surface ozone measurements in Amazonia. J. Geophys. Res., v. 93, pp. 1469 -1476.

Madronich, S. and Granier, C. (1992) Impact of recent total changes on tropospheric ozone photo dissociation, hydroxyl radicals, and methane trends, Geophys. Res. Lett., v. 19, pp. $465-467$.

Ripperton, L. A. and Vukovich, F. M. (1971) Gas phase destruction of tropospheric ozone. J. Geophys. Res., v. 76(30), pp. 7328-7333.

Shiotani, M. (1992) Annual quasi-biennial and El Nino-Southern Oscillation (ENSO) time-scale variations in equatorial ozone. J. Geophys. Res., v. 97, pp. 7625-7633.

Solomon, K. R., Tang,X., S. R., Wilson, S. R., Zanis, P. and Bais, A. F. (2003) Changes in tropospheric composition and air quality due to stratospheric ozone depletion.Photochem. Photobiol. Sci., v. 2, pp. 62-67. 
Thompson, A. M., Stewart, R. W., Owens, M. A. and Herwehe, J. A. (1989) Sensitivity of tropospheric oxidants to global chemical and climate change, Atmos. Environ., v. 23, pp. $519-532$.

Towards cleaner air: A case study of New Delhi. Department of Environment, Government of NCT of Delhi \& Delhi Pollution Control Committee (http://dpcc.delhigovt.nic.in/pdf/cleanerair.pdf)

Tremmel, H. G., Schlager, H., Konopka, P., Schulte, P., Arnold, F., Klemm, M. and Droste - Franke, B. (1998) Observations and model calculations of jet aircraft exhaust products at cruise altitude and inferred initial OH emissions. J. Geophys. Res., v. 103, pp. 10803 -10816.

Van Dop, H., Guicherit, R. and Lanting, R.W. (1977) Some measurements of the vertical distribution of ozone in the atmospheric boundary layer. Atmos. Environ., v. 11, pp. $65-71$

Wang, W. C. and Isaksen, I. S. A. (1995) Atmospheric ozone as a climate gas. General circulation model simulations, Series I, v. 32, pp. 73.

Weatherhead, E. C. and Andersen, S. B. (2006) The search for signs of recovery of the ozone layer. Nature, v. 441, pp. 39-45.

World Meteorological Organization, Scientific Assessment of Ozone depletion: 1994, (1995) Report 37, Global ozone research and monitoring project, WMO Geneva.

(Received: 23.10.2013; Accepted 13.01.2014) 